\title{
Kleptoparasitism by Eurasian Buzzard (Buteo buteo) on Two Falco Species
}

KEY WORDs: Eurasian Buzzard; Buteo buteo; Falco spp.; kleptoparasitism.

Interspecific kleptoparasitism in raptors may sometimes be an important strategy for obtaining food. Within the genus Buteo, a few species are victims of this behavior (e.g., Jorde and Lingle 1988, J. Field Ornithol. 59:183-188), but some species have also been observed stealing prey from smaller raptors (e.g., Beebe 1960, Condor 62:480-481; Paulson 1985, Auk 102:637-639; Woffinden 1986, Great Basin Nat. 46:302-304; Enderson et al. 1995, J. Raptor Res. 29:93-98). In the case of the Eurasian Buzzard (Buteo buteo), kleptoparasitism seems to be unusual (Cramp and Simmons 1980, The birds of the western palearctic, Vol. 2, Oxford Univ. Press, Oxford, U.K.). Here, we report two cases of kleptoparasitism by the Canary Islands subspecies of the Eurasian Buzzard (B. b. insularum) on two sympatric Falco species on Tenerife Island.

Tenerife is the largest $\left(2034 \mathrm{~km}^{2}\right)$ and highest $(3718 \mathrm{~m})$ island in the Canarian archipelago $\left(27-29^{\circ} \mathrm{N}\right.$ and $\left.13-18^{\circ} \mathrm{W}\right)$. Two decades ago, it was estimated that 170-180 pairs of buzzards inhabited this island (Quilis et al. 1993, Vieraea 22:8996), and this number seems not to have changed significantly since then. The most densely populated areas are Anaga 
and Teno, two abrupt massifs in the northeastern and northwestern ends of the island, respectively. The following observations took place at Las Cuevas ravine, one of the breeding territories on the Teno massif.

On 13 July 2005, a Barbary Falcon (Falco peregrinus pelegrinoides) was observed flying near a buzzard breeding cliff (ca. $400 \mathrm{~m}$ from an occupied nest) with a dead Rock Pigeon (Columba livia) clutched in its talons. Subsequently, the buzzard pair chased the falcon and made aggressive dives toward it. After approximately $30 \mathrm{sec}$, the Barbary Falcon with its prey, and with the two buzzards in pursuit, flew into the ravine, where we could not observe them. A few minutes later, a Barbary Falcon (probably the same one observed previously, but now without its prey) attacked and forced a buzzard to the ground, where it stayed for about $10 \mathrm{~min}$. After this interaction, the falcon flew away.

On 13 October 2006, a buzzard on the same territory pursued for almost $60 \mathrm{sec}$ an adult female Eurasian Kestrel $(F$. tinnunculus) that was gripping a lizard (Gallotia sp.) in its talons. The kestrel was forced to drop its prey and the buzzard caught the lizard in flight and went toward a scarp in the ravine, where it was later seen feeding on the prey.

In the first observation, although it was clear that the falcon lost its prey due to the buzzards' pressure, we could not rule out the possibility of territorial defense rather than kleptoparasitism, as there were fledglings in the buzzard territory. However, our observations suggested kleptoparasitism, because, after the buzzards' harassment ended, we could see only one of them, and we believed the other may have been feeding on the dove. Our supposition was supported by the fact that kleptoparasitism by Eurasian Buzzard on Peregrine Falcons ( F. peregrinus), although not frequent, has been previously documented (Zuberogoitia et al. 2002, El Halcón Peregrino, Diputación Foral de Bizkaia, Bizkaia, Spain).

After the second interaction occurred, we observed $1310 \mathrm{~min}$ in the territory of Las Cuevas ravine during the period October-December 2006, and detected no more cases of kleptoparasitism. Furthermore, no other cases of kleptoparasitism were recorded in $30 \mathrm{yr}$ of watching buzzards in the Canary Islands (F. Siverio unpubl. data). The rugged, steep terrain of Tenerife and many other oceanic islands may prevent raptors from seeing and interacting with each other, which might hamper the occurrence of kleptoparasitism, given that the ecological factors that facilitate such behavior include a concentration of potential hosts and open habitats (Brockmann and Barnard 1979, Anim. Behav. 27:487-514; Paulson 1985). Moreover, kleptoparasitism in some raptors has been considered to be a learned foraging technique (Jorde and Lingle 1988). Consequently, one would expect that for this behavior to appear and persist through time, very favorable conditions must coincide. In addition, the paucity of reports of kleptoparasitism by Eurasian Buzzards, throughout its entire distribution, suggests the highly occasional nature of this behavior.

We are grateful to Ayuntamiento de la Villa Histórica de Santiago del Teide for support. We also thank Beneharo Rodríguez, Rubén Barone, Manuel Siverio, Reto Burri and Vincenzo Penteriani for help during different phases of this work.-Felipe Siverio (e-mail address: felipe.siverio@telefonica.net), Los Barros 21, 38410 Los Realejos, Tenerife, Canary Islands, Spain; Airam Rodríguez, Estación Biológica de Doñana (CSIC), Avda. María Luisa s/n, 41013 Seville, Spain; and David P. Padilla, Island Ecology and Evolution Research Group (IPNA-CSIC), Astrofísico Fco. Sánchez 3, 38206 La Laguna, Tenerife, Canary Islands, Spain.

Received 17 May 2007; accepted 26 November 2007

Associate Editor: Vincenzo Penteriani 